\title{
Low sequence diversity of the prion protein gene $(P R N P)$ in wild deer and goat species from Spain
}

\author{
José Luis Pitarch, Helen Caroline Raksa ${ }^{1}$, María Cruz Arnal², Miguel Revilla², David Martínez², \\ Daniel Fernández de Luco², Juan José Badiola', Wilfred Goldmann ${ }^{3}$ and Cristina Acín ${ }^{1 *}$ (1)
}

\begin{abstract}
The first European cases of chronic wasting disease (CWD) in free-ranging reindeer and wild elk were confirmed in Norway in 2016 highlighting the urgent need to understand transmissible spongiform encephalopathies (TSEs) in the context of European deer species and the many individual populations throughout the European continent. The genetics of the prion protein gene (PRNP) are crucial in determining the relative susceptibility to TSEs. To establish PRNP gene sequence diversity for free-ranging ruminants in the Northeast of Spain, the open reading frame was sequenced in over 350 samples from five species: Iberian red deer (Cervus elaphus hispanicus), roe deer (Capreolus capreolus), fallow deer (Dama dama), Iberian wild goat (Capra pyrenaica hispanica) and Pyrenean chamois (Rupicapra p. pyrenaica). Three single nucleotide polymorphisms (SNPs) were found in red deer: a silent mutation at codon 136, and amino acid changes T98A and Q226E. Pyrenean chamois revealed a silent SNP at codon 38 and an allele with a single octapeptide-repeat deletion. No polymorphisms were found in roe deer, fallow deer and Iberian wild goat. This apparently low variability of the PRNP coding region sequences of four major species in Spain resembles previous findings for wild mammals, but implies that larger surveys will be necessary to find novel, low frequency PRNP gene alleles that may be utilized in CWD risk control.
\end{abstract}

\section{Introduction}

Transmissible spongiform encephalopathies (TSEs) are a group of fatal, neurodegenerative disorders characterised by the accumulation in the central nervous system of prion protein $\mathrm{PrP}^{\mathrm{Sc}}$, an abnormal isoform of the cellular protein $\operatorname{PrP}^{\mathrm{C}}[1,2]$. TSEs can affect several mammalian species, but show a predominance in ruminants: scrapie in sheep and goats, bovine spongiform encephalopathy (BSE) in bovids and chronic wasting disease (CWD) in cervids.

Scrapie is a widespread disease known for more than 250 years, which is present in almost all regions of the world [3], while BSE reached epidemic proportions in Europe in the 1990s due to the use of animal feedstuffs contaminated with prions [4]. Both TSEs affected livestock and exotic ruminants in zoological collections, but

\footnotetext{
*Correspondence: crisacin@unizar.es

${ }^{1}$ Centro de Encefalopatías y Enfermedades Transmisibles Emergentes,

Facultad de Veterinaria, Universidad de Zaragoza, Zaragoza, Spain

Full list of author information is available at the end of the article
}

there is no evidence that any wild and free-ranging ruminants suffered natural scrapie or BSE.

In contrast, CWD has affected North American freeranging mule deer, white tailed deer and wapiti. Originally centred in Colorado, Wyoming and Southwest Canada [57], CWD has now spread through many US states, mostly in captive wapiti and deer, including a captive red deer from a herd located in Minnesota [8]. Additionally, chronic wasting disease has been orally transmitted to Shira's moose [9], red deer [10], reindeer [11] and Reeves' muntjac deer [12], but only by intracerebral inoculation to fallow deer [13]. Although natural transmission of CWD to humans seems unlikely, several studies recommend establishing preventive measures and further research on the subject $[14,15]$.

The presence of CWD in Europe was confirmed recently: reindeer (Rangifer tarandus) and European elk (Alces alces) were diagnosed in two separated regions of Norway $[16,17]$. There is no evidence for CWD among other European deer populations [18]. 
Susceptibility to any TSE depends largely on the $\operatorname{PrP}^{\mathrm{C}}$ sequence, encoded by the host PRNP gene. Several studies of natural and experimental scrapie infection in sheep and goats showed how allelic variations in the PRNP gene modulates disease susceptibility $[19,20]$, and it is therefore critical to consider the PRNP gene sequence in wild ruminants for the assessment of TSE infection risk.

Studies of CWD in North America have indicated several amino acid substitutions in $\mathrm{PrP}^{\mathrm{C}}$ that are associated with different susceptibility to disease. In wapiti (or Rocky Mountain elk, Cervus canadensis nelsoni) polymorphism M132L appears to modulate disease [21-24], in mule deer (Odocoileus hemionus) it is polymorphism S225F $[25,26]$ and in white-tailed deer (Odocoileus virginianus) polymorphisms G96S, Q95H and A116G are modulators [27-29]. Only limited genotype survey data exist for European deer populations. Similarly, a survey between the years 2007 and 2009 of 537 wild red deer from Spain tested negative for the presence of $\mathrm{PrP}^{\mathrm{Sc}}$ as did all other European surveys conducted in parallel. Since then, no further diagnostic reports have been published for any cervid in Spain.

The area of this study was located at the Northeast of Spain, between the mountain chain of the Pyrenees and the Iberian System, spanning the whole region of Aragon, part of La Rioja and the eastern side of Castilla y Leon. In these locations, there are five mayor species of wild ruminants: Iberian red deer (Cervus elaphus hispanicus), roe deer (Capreolus capreolus), fallow deer (Dama dama), Iberian wild goat (Capra pyrenaica hispanica) and Pyrenean chamois (Rupicapra p. pyrenaica). Pyrenean chamois and Iberian wild goat belong to the family Bovidae, subfamily Caprinae and are theoretically at risk to scrapie or BSE infection. Red deer, fallow deer and roe deer represent two subfamilies of cervids (Cervinae and Capreolinae) which are at risk CWD infection.

An estimation of the total population of the different species in the North East area has been revised. In this sense, the population estimated for the deer population is about 6500 individuals. More prolific and represented is the roe deer with 23600 individuals and finally totally of 13000 and 7200 is the estimation for Pyrinean Chamois and Iberian wild goat [30, 31].

The aim of this work was to study the PRNP gene of the different species of wild ruminants of the Northeast area of Spain in order to evaluate their status of resistance or susceptibility to prion diseases.

\section{Materials and methods}

\section{Animals and samples}

This study includes 351 animals of five different species of wild ruminants: Iberian red deer (Cervus elaphus hispanicus), roe deer (Capreolus capreolus), fallow deer
(Dama dama), Iberian wild goat (Capra pyrenaica hispanica) and Pyrenean chamois (Rupicapra p. pyrenaica). All of them were free-ranging animals from different places of northeast of Spain, and were hunted or found dead in game reserves or hunting grounds (Figure 1).

Red deer $(n=209)$ were grouped into three areas according to their geographical proximity. The west area (WA) combined 70 animals from the hunting grounds of Arancon $(n=13)$, Renieblas $(n=9)$ and Ezcaray $(n=48)$. The east area (EA) combined 128 animals from the hunting grounds of Caspe $(n=50)$ and Fraga $(n=78)$. The south area (SA) is represented by 11 animals from the game reserve of Montes Universales; this area was also the origin of the fallow deer samples $(n=15)$. Roe deer and Pyrenean chamois $(n=44 ; n=53)$ came from the Pyrenean game reserves of Los Valles $(n=2 ; n=11)$, Viñamala $(\mathrm{n}=10 ; n=9)$, Los Circos $(n=4 ; n=13)$ and Benasque $(n=15 ; n=20)$; and from several hunting grounds of West Aragon $(n=13)$. Iberian wild goats came from different hunting grounds located in SouthEast Aragon $(n=30)$. Spleen samples from all animals of the study were collected and kept frozen $\left(-20^{\circ} \mathrm{C}\right)$ in order to extract the genomic DNA. Samples of obex, tonsil or ileocecal valve were collected from 68 red deer from the hunting grounds of Caspe $(n=32)$, Fraga $(n=26)$ and

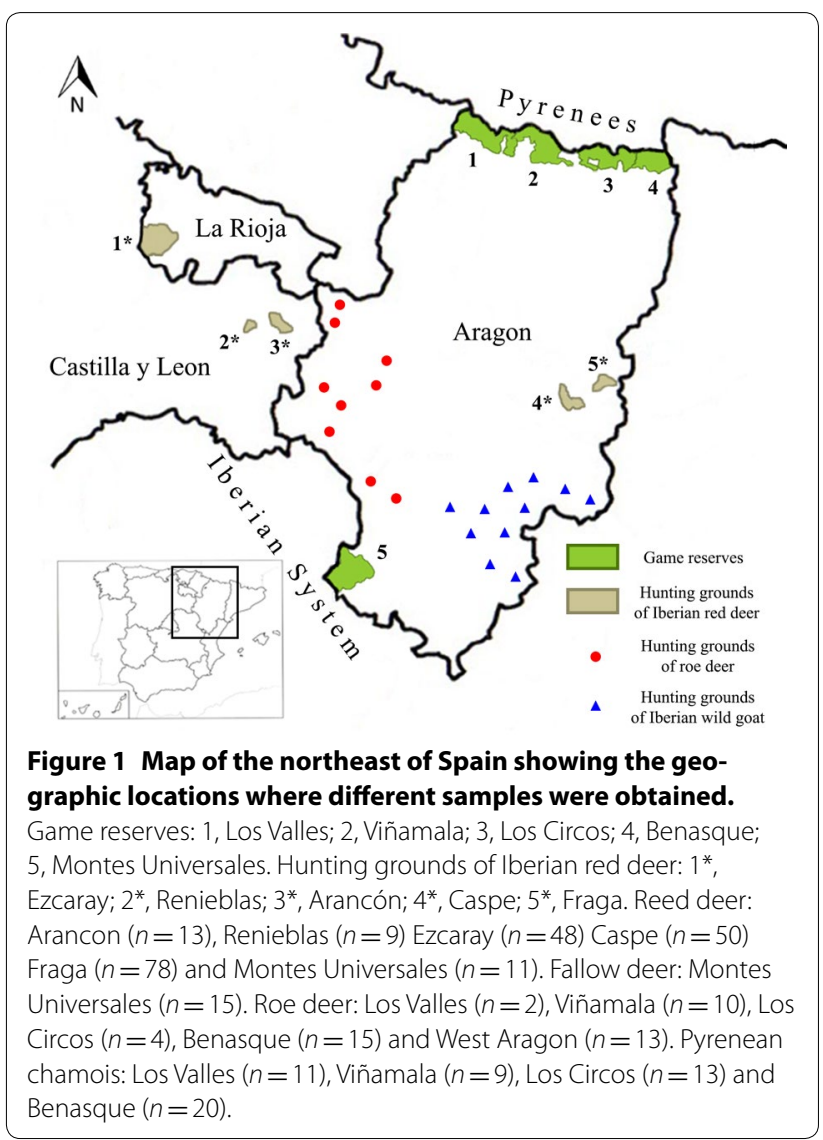


Renieblas $(n=10)$, they were preserved in $10 \%$ neutral buffered formaldehyde and embedded in paraffin for TSE diagnosis.

\section{Extraction and purification of genomic DNA}

Genomic DNA was extracted from $500 \mathrm{mg}$ of spleen using a QIAamp DNA mini kit $\left(\right.$ QIAGEN $\left.^{\circledR}\right)$ following the manufacturers protocol. In brief, two digestions of $1 \mathrm{~h}$ at $56{ }^{\circ} \mathrm{C}$ with proteinase $\mathrm{K}(20 \mathrm{ng} / \mathrm{mL})$ lysed the cells of the tissue. Then, by using a membrane column, ethanol was added to assist the precipitation of DNA and binding to the membrane. Finally, a series of washes removed debris and then purified genomic DNA was recovered.

\section{PRNP gene amplification and sequencing}

The open reading frame (ORF) of PRNP gene (771 bp) of all animals except fallow deer was amplified by performing a PCR using the reagents of the commercial kit of QIAGEN $^{\circledR}$ (HotStarTaq $^{\circledR}$ Master Mix Kit) and primers SILV-8 (fwd) (5'-AAAGCCACATAGGCAGC TGGAT-3') and SILV-778 (rev) (5'-AGAAGATAATGAA AACAGGAAG-3') [21] for roe and red deer; and PrP8 (fwd) (5'-CAGGTTAACGATGGTGAAAAGCCACATA GG-3') andPrP9 (rev) (5'-GGAATTCTATCCTACTATGA GAAAAATGAGG-3') [32] for Iberian wild goat and Pyrenean chamois. PCR reactions were purified using the vacuum manifold from Millipore ${ }^{\circledR}$. Bi-directional sequencing was performed using the same PCR primers. Chromatograms were analysed using BioEdit v.4.8.6.

Fallow deer samples were PCR amplified with AmpliTaq Gold360 (Thermo Fisher Scientific) using either primer -143d (ATGGAATGTGAAGAACATTTATGACCTA) or primer -213d (AGGTCAACTTTGTCCTTGGAGGA G) in combination with primer $+139 \mathrm{u}$ (TAAGCGCCAA GGGTATTAGCAT). Sequences were generated as described in Goldmann et al. [33] with oligonucleotide +70u GCTGCAGGTAGATACTCCCTC.

New sequences were deposited in Genbank with the following accession numbers: Cervus elaphus hispanicus KT845862-KT845864, Capra pyrenaica hispanica KT845865, Rupicapra pyrenaica pirenaica KT845866-KT845868.

\section{Statistical analysis}

The results obtained for different subpopulations are compared statistically using the Fisher exact test of $2 \times 2$ and $2 \times 3$ contingency tables, with $p<0.05$ considered significant. The computer program GENEPOP was used to perform a statistical test to determine possible deviations from the Hardy-Weinberg equilibrium.

\section{PrP $^{\text {sc }}$ immunohistochemical detection} and haematoxylin-eosine stain

Sections of $5 \mu \mathrm{m}$ of formaldehyde-fixed and paraffinwax-embedded lymphoid tissues and obex were subjected to immunohistochemical diagnosis of CWD using MAb F99/97.6.1, a mouse monoclonal antibody antiPrP [34]. In addition, tissue sections were stained with haematoxylin and eosin (HE), in order to observe possible histopathological lesions.

\section{Results}

\section{Deer PRNP}

The coding region of the PRNP gene from 209 Iberian red deer samples collected in North-East Spain showed three single-nucleotide polymorphisms (SNPs): a silent SNP at position 408 (codon 136) (gct $\rightarrow$ gcc), and two polymorphisms at positions 292 (acc $\rightarrow$ gcc) and 776 ( $\mathrm{cag} \rightarrow$ gag), resulting in amino acid changes in codons 98 and 226. The mutation in codon 98 causes an amino acid substitution of threonine $(\mathrm{T})$ with alanine $(\mathrm{A})$, while in codon 226 the mutation results in an amino acid change from glutamine $(\mathrm{Q})$ to glutamic acid (E). The SNP at nucleotide position 408 is linked to the SNP at position 776, so that all haplotypes were either $\mathrm{t} 408-\mathrm{a} 776\left(\mathrm{Q}_{226}\right)$ or c408-g776 $\left(\mathrm{E}_{226}\right)$; Tables 1 and 2 only show the amino acid changes. $\mathrm{A}_{98}$ was observed 61 times in linkage with $\mathrm{Q}_{226}$, and all $\mathrm{AA}_{98}$ homozygous genotypes were $\mathrm{QQ}_{226}$ homozygous. Therefore, it is assumed that $\mathrm{A}_{98}$ was also linked with $\mathrm{Q}_{226}$ in the $28 \mathrm{TA}_{98}-\mathrm{QE}_{226}$ heterozygotes so that their genotype can be described as TE/AQ. The three haplotypes described here for Spanish red deer were identical to haplotypes 1, 8 and 10 found in Italy and Scotland [35].

The SNPs in codons 136 and 226 appeared in all the three geographic areas, while the polymorphism at codon 98 appeared in deer from EA and WA, but not SA. The allele and genotype frequencies of the amino acid polymorphisms were calculated for the whole population, and separately for the different subpopulations in EA, WA and SA (Tables 1 and 2). Allele frequencies for the TQ and TE alleles were $74.3 \%$ in the EA, 83.6\% in the WA and $100 \%$ in the SA. Correspondingly, frequencies for the AQ allele were $25.7 \%$ in the EA, $16.4 \%$ in the WA and $0 \%$ in the SA. The lack of the AQ allele from the SA population is significant compared with the EA $(p=0.003)$ and WA $(p=0.045)$ populations although only 11 animals were collected. When the EA and WA populations are compared for the $\mathrm{AQ}$ allele frequencies, the difference of $9.3 \%$ was also significant $(p=0.03)$. However, there was no significant difference between TQ and TE alleles when any 
Table 1 Genotypic frequencies (\%) of PRNP polymorphisms in Iberian red deer from the North-East of Spain

\begin{tabular}{|c|c|c|c|c|c|c|c|}
\hline \multirow{2}{*}{$\begin{array}{l}\text { Codon } 98 \\
\text { Thr(T) } \\
\text { Ala(A) }\end{array}$} & \multirow{2}{*}{$\begin{array}{l}\text { Codon } 226 \\
\text { Gln(Q) } \\
\text { Glu(E) }\end{array}$} & \multirow[t]{2}{*}{ Genotypes } & \multirow[t]{2}{*}{ Number } & \multicolumn{4}{|c|}{ Frequencies (\%) } \\
\hline & & & & Total & $\mathrm{EA}$ & WA & SA \\
\hline $\mathrm{TT}$ & $\mathrm{QQ}$ & $\mathrm{TQ} / \mathrm{TQ}$ & 44 & 21.05 & 18.8 & 24.3 & 27.3 \\
\hline TT & QE & $\mathrm{TQ} / \mathrm{TE}$ & 56 & 26.8 & 23.4 & 30 & 45.4 \\
\hline $\mathrm{TT}$ & $\mathrm{EE}$ & $\mathrm{TE} / \mathrm{TE}$ & 33 & 15.8 & 14.1 & 17.1 & 27.3 \\
\hline TA & QQ & $\mathrm{TQ} / \mathrm{AQ}$ & 35 & 16.75 & 19.5 & 14.3 & 0 \\
\hline AA & QQ & $\mathrm{AQ} / \mathrm{AQ}$ & 13 & 6.2 & 7.8 & 4.3 & 0 \\
\hline TA & QE & TE/AQ & 28 & 13.4 & 16.4 & 10 & 0 \\
\hline - & - & TOTAL & 209 & 100 & 100 & 100 & 100 \\
\hline
\end{tabular}

T: threonine, A: alanine, Q: glutamine, E: glutamic acid, EA: east area, WA: west area, SA: south area.

Table 2 Allelic frequencies (\%) of PRNP polymorphisms in EA and WA subpopulations of Iberian red deer

\begin{tabular}{lccccrr}
\hline Alleles Codons 98-226 & Haplotype in Peletto et al. [34] & Number & \multicolumn{3}{c}{ Allele Frequencies (\%) } \\
\cline { 4 - 7 } & & & Total & EA & WA & SA \\
\hline TQ & 1 & 179 & 42.8 & 40.3 & 46.4 \\
TE & 10 & 150 & 35.9 & 34 & 37.2 & 50 \\
AQ & 8 & 89 & 21.3 & 25.7 & 16.4 & 0 \\
Total & & 418 & 100 & 100 & 100 & 100
\end{tabular}

T: threonine, A: alanine, Q: glutamine, E: glutamic acid, EA: east area; WA: west area, SA: south area.

of the three populations were compared; on average both alleles appear balanced at $53.2 \%$ and $46.8 \%$, respectively. Both subpopulations EA and WA are in HWE for the three SNPs. When the allele frequencies of the Alpine red deer Cervus elaphus elaphus (AQ:TQ:TE = 10\%:62\%:28\%) [35] was compared to the Spanish red deer Cervus elaphus hispanicus (21.3\%:42.8\%:35.9\%) the differences were significant $(p=0.03)$, with an increased frequency of the AQ allele.

The 15 fallow deer PRNP coding region sequences (codon 23-256) showed no SNP at all, matching the red deer haplotype $t 408-a 292\left(\mathrm{~T}_{98}\right)-\mathrm{g} 776\left(\mathrm{E}_{226}\right)$, but with the previously described codon 138 sequence aat $\left(\mathrm{N}_{138}\right)$ deposited in Genbank (accession no. AY286007). Similarly, all 44 roe deer PRNP coding region sequences were identical to each other and to the published sequence of roe deer (Accession No. AY639096). The roe deer allele is identical to the red deer TQ allele.

\section{Iberian wild goat and chamois $P R N P$}

The PRNP allele deduced from 30 Iberian wild goat sequences was identical to the Alpine ibex (Capra ibex ibex, accession no. EF139174) and Nubian ibex (Capra ibex nubiana, AF117319). It showed no polymorphisms. Finally, the PRNP coding region sequences of 53 Pyrenean chamois revealed the presence of a silent mutation at position 114 (gga $\rightarrow$ ggg, codon 38 ) and a 24 bp deletion, but was otherwise identical to Alpine chamois (Accession No. AY735496.1). The g114 haplotype was found at a frequency of $13.2 \%$. The 24 bp deletion (tcagccccatggaggtggctgggg) causes the loss of one octapeptide (PHGGGWGQ) of the standard five repeats in the N-terminal region of the wild type PrP protein, it was observed in eight heterozygous animals (allele frequency $0.9 \%$ ).

\section{Histological analysis for $\mathrm{PrP}^{\mathrm{sc}}$ deposition in red deer}

$\mathrm{PrP}^{\mathrm{Sc}}$ immunoreactivity was assayed in obex and lymphoid tissue (tonsil and/or ileocecal valve) in 54 animals and in lymphoid tissue only in an additional 14 animals. Animals of all genotypes were selected: TE/AQ (14), AQ/ TQ (18), TE/TE (8), TQ/TQ (12) and TE/TQ (16). None of these 68 animals showed any $\mathrm{PrP}^{\mathrm{Sc}}$ in any of the tissues (Figure 2). Other, non-TSE histological observations included CNS injuries that may be associated with the time of death of the animal, such as perivascular haemorrhages, observed in $35 \%$ of the animals. Furthermore, the presence of mild lymphoplasmacytic perivascular cuffing and gliosis foci was detected in 15\%, not associated to any particular cause such as unspecific inflammation. Anyway, no microscopic lesion that could correspond to those characteristics of TSE was observed in the brain of the animals. 

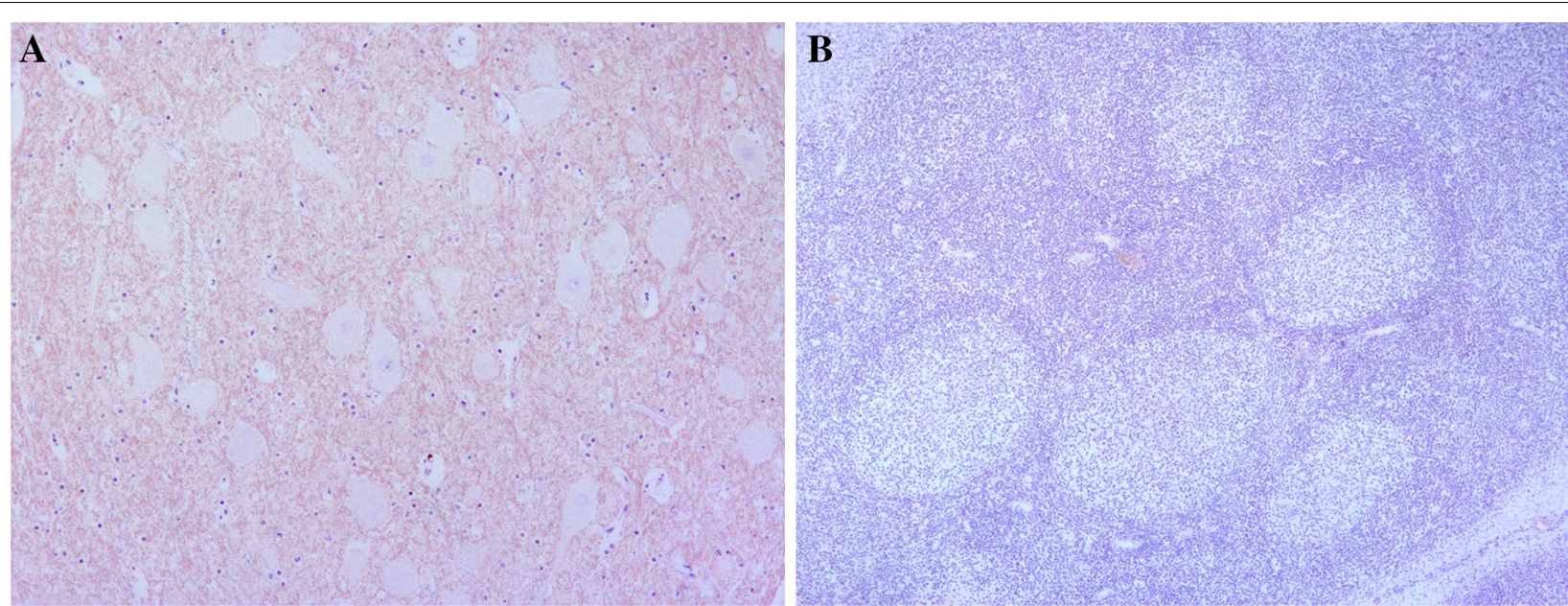

Figure 2 Absence of PrPsc in central nervous system and lymphoreticular system of Iberian red deer. Absence of deposition of PrPsc in histological sections of brain at level of dorsal motor nucleus of the vague nerve $(10 \times)(\mathbf{A})$, and tonsil $(10 \times)(\mathbf{B})$ of an Iberian red deer by immunohistochemistry using antibody F99/97.6.1.

\section{Discussion}

The analysis of 700 PRNP gene coding regions from three cervine and two wild caprine species revealed only three amino acid polymorphisms in $\operatorname{PrP}^{\mathrm{C}}$, and an additional two synonymous SNPs. Whilst the cervine polymorphisms have been described before, the two polymorphisms in the chamois were new.

The two amino acid substitutions T98A and Q226E detected in Iberian red deer have both previously been described in an Italian red deer PRNP gene survey, in the same allele combination of AQ, TQ and TE. There is a significant difference in the allele frequencies between the Italian, British and Spanish populations but its relevance for CWD remains to be investigated [35]. The PRNP polymorphism M132L described in the related North American wapiti (Rocky mountain elk) has not been found yet in any European red deer [21, 24].

Threonine in codon 98 appears to be the most commonly found amino acid in this position, including human $\operatorname{PrP}^{\mathrm{C}}$. While a serine substitution in codon 98 is found in sheep, goats and muntjac deer amongst many others, the replacement with alanine is much rarer, seen only in red deer, camel, two monkey species and armadillo. Although the T-S-A substitutions have to be regarded as conservative, they may still have a role in the conversion of $\operatorname{PrP}^{C}$ into the pathogenic form $\operatorname{PrP}^{S c}$ that is found in CWD and all other prion diseases. This codon position is not only very close to the proteinase $\mathrm{K}$ cleavage site of the partially resistant $\mathrm{PrP}^{\mathrm{Sc}}$ protein fragment, it is also near codons 95 and 96, which are associated with susceptibility to CWD of white-tailed and mule deer [27-29].
Codon 226 is located in the third $\alpha$-helix of $\operatorname{PrP}^{\mathrm{C}}$ and remains part of the proteinase $\mathrm{K}$ resistant fragment of $\mathrm{PrP}^{\mathrm{Sc}}$. It may therefore play a role in the stability and conversion of $\operatorname{PrP}^{\mathrm{C}}$. Indeed, many amino acid substitutions in helix 3, particularly in human $\operatorname{PrP}^{\mathrm{C}}$, have been shown to change the propensity for prion disease development. On the other side, substitutions in codon 222 in caprine $\operatorname{PrP}$ or the equivalent position 219 in human $\operatorname{PrP}$ are associated with strong disease resistance. Equally, polymorphism S225F seems to play a role in CWD resistance in mule deer [25]. In white-tailed deer another codon 226 polymorphism, Q226K, was found at low frequency [29].

Recent experimental CWD challenge studies in red deer have been performed which coincidentally used animals with all three codon 226 genotypes $\left(\mathrm{QQ}_{226}, \mathrm{QE}_{226}\right.$, $\left.\mathrm{EE}_{226}\right)$. There were no significant differences in $\mathrm{PrP}^{\mathrm{Sc}}$ western blot profiles or in the incubation times associated with those genotypes, but the number of animals in the study was far too small to come to a significant conclusion regarding genetic association [10]. Another experiment showed that European red deer with QQ226 genotype were susceptible to intracerebral challenge with BSE brain homogenate [36]. A similar study using BSE by oral route let to disease in a $\mathrm{QQ}_{226}$ deer, while the other genotypes $\left(\mathrm{EE}_{226}, \mathrm{QE}_{226}\right)$ remained healthy [37]. Then again, the number of animals with particular genotypes was too small to establish genetic association with susceptibility or pathogenesis.

The analysis for disease-associated deposition of $\operatorname{PrP}^{\mathrm{Sc}}$ by immunocytochemistry in cervine tissues from 68 animals has given a negative result, which at least indicates that CWD is not hiding as non-clinical disease epidemic 
in Spanish red deer. Of course many more samples need to be studied to allow for a definite assessment regarding the absence of CWD from these and neighbouring populations.

No PRNP sequence variation was found in approx. 120 chromosomes analysed for Iberian roe and fallow deer, which is not dissimilar to the Italian and Swedish studies, which revealed one synonymous polymorphism in approx. 420 chromosomes between them [35, 38]. Only further extensive genotyping of these species will prove whether they have indeed a particularly low $P R N P$ coding region variability.

Animals from the subfamily Caprinae, like Pyrenean chamois and Iberian wild goat, are thought to be susceptible to scrapie because of the close resemblance of their PRNP sequence with domestic goat PRNP [39]. The deletion in the octapeptide region observed in one Pyrenean chamois is a novel polymorphism for this species, but octapeptide repeat deletions in $\operatorname{PrP}^{\mathrm{C}}$ have been found regularly in several species. Approximately $10 \%$ of $\mathrm{PrP}^{\mathrm{C}}$ from over 140 species have shown deletions of one, two or even three octapeptides, whilst the opposite, a single octapeptide insertion has been found in 15\% of PrP alleles. Whether an association exists between octapeptide number variation and TSE in ruminants remains unresolved.

CWD, the most important TSE affecting cervids, has been confined to North America for years, but finally it has reached the European continent. Its great capacity for dissemination means that, eventually it could reach other regions from Europe, including the Iberian Peninsula. Besides, a real contact with the causal agent of scrapie occurs constantly because of the extensive grazing areas shared by the population of wild ruminant, especially red deer, and sheep and goats flocks. In addition, the great capacity of prion to jump between species [40] poses a risk to these deer $[41,42]$.

This survey has shown that the PRNP gene is highly conserved in four important species of wild ruminants in the northeast of Spain and supports the current assumption that there is no hidden TSE epidemic in red deer.

\footnotetext{
Abbreviations

CWD: chronic wasting disease; TSE: transmissible spongiform encephalopathy; PRNP: prion protein gene; SNP: single nucleotide polymorphism; BSE: bovine spongiform encephalopathy; WA: west area; EA: east area; SA: south area.

\section{Competing interests}

The authors declare that they have no competing interests.

\section{Authors' contributions}

CA designed the study. JLP, MCA, MR, DM, DFL and CA collected the samples. $J \mathrm{LP}$ and HCR performed the DNA extraction, PCRs, immunohistochemistry and HE. JLP, HCR and CA analysed the data. JLP and CA wrote the manuscript with contributions and editing from HCR, MCA, MR, DM, DFL, JJB and WG. All authors read and approved the final manuscript.
}

\section{Acknowledgements}

Authors thank to the hunters and guards of the hunting grounds of Aragon for their collaboration in sampling, and Yolanda Gracia, Sonia Gómez, Silvia Ruíz, Nuria Segovia and Helen Williamson for their technical assistance.

\section{Availability of data and materials}

The datasets used and/or analysed during the current study are available from the corresponding author on reasonable request.

\section{Ethics approval and consent to participate}

Not applicable.

\section{Funding}

Funding for this project was provided by the Department of Agriculture, Livestock and Environment of the Aragón Government and the Ministry of Agriculture and Fisheries, Food and Environment of Spain.

\section{Author details}

${ }^{1}$ Centro de Encefalopatías y Enfermedades Transmisibles Emergentes, Facultad de Veterinaria, Universidad de Zaragoza, Zaragoza, Spain. ${ }^{2}$ Departamento de Patología Animal, Facultad de Veterinaria, Universidad de Zaragoza, Zaragoza, Spain. ${ }^{3}$ The Roslin Institute and Royal (Dick) School of Veterinary Studies, University of Edinburgh, Easter Bush, Midlothian, UK.

\section{Publisher's Note}

Springer Nature remains neutral with regard to jurisdictional claims in published maps and institutional affiliations.

Received: 18 December 2017 Accepted: 12 March 2018

Published online: 10 April 2018

\section{References}

1. Prusiner SB (1982) Novel proteinaceous infectious particles cause scrapie. Science 216:136-144

2. Kong Q, Bessen RA (2008) Prion Diseases. In: Gendelman HE, Ikezu T (eds) Neuroimmune Pharmacology. Springer, Boston

3. Detwiler LA, Baylis M (2003) The epidemiology of scrapie. Rev Sci Tech 22:121-143

4. Wilesmith JW, Ryan JB, Hueston WD, Hoinville LJ (1992) Bovine spongiform encephalopathy: epidemiological features 1985 to 1990. Vet Rec 130:90-94

5. Williams ES, Young S (1992) Spongiform encephalopathies in Cervidae. Rev Sci Tech 11:551-567

6. Spraker TR, Miller MW, Williams ES, Getzy DM, Adrian WJ, Schoonveld GG, Spowart RA, O'Rourke KI, Miller JM, Merz PA (1997) Spongiform encephalopathy in free-ranging mule deer (Odocoileus hemionus), white-tailed deer (Odocoileus virginianus) and Rocky Mountain elk (Cervus elaphus nelsoni) in northcentral Colorado. J Wild Dis 33:1-6

7. Williams ES, Miller MW (2002) Chronic wasting disease in deer and elk in North America. Rev Sci Tech 21:305-316

8. Schwabenlander MD, Culhane MR, Hall SM, Goyal SM, Anderson PL, Carstensen M, Wells SJ, Slade WB, Armien AG (2013) A case of chronic wasting disease in a captive red deer (Cervus elaphus). J Vet Diagn Invest 25:573-576

9. Kreeger TJ, Montgomery DL, Jewell JE, Schultz W, Williams ES (2006) Oral transmission of chronic wasting disease in captive Shira's moose. J Wildl Dis 42:640-645

10. Balachandran A, Harrington NP, Algire J, Soutyrine A, Spraker TR, Jeffrey M, Gonzalez L, O'Rourke KI (2010) Experimental oral transmission of chronic wasting disease to red deer (Cervus elaphus elaphus): early detection and late stage distribution of protease-resistant prion protein. Can Vet J 51:169-178

11. Mitchell GB, Sigurdson CJ, O'Rourke Kl, Algire J, Harrington NP, Walther I, Spraker TR, Balachandran A (2012) Experimental oral transmission of chronic wasting disease to reindeer (Rangifer tarandus tarandus). PLoS One 7:e39055 
12. Nalls AV, McNulty E, Powers J, Seelig DM, Hoover C, Haley NJ, Hayes-Klug J, Anderson K, Stewart P, Goldmann W, Hoover EA, Mathiason CK (2013) Mother to offspring transmission of chronic wasting disease in Reeves' muntjac deer. PLoS One 8:e71844

13. Hamir AN, Greenlee JJ, Nicholson EM, Kunkle RA, Richt JA, Miller JM, Hall M (2011) Experimental transmission of chronic wasting disease (CWD) from elk and white-tailed deer to fallow deer by intracerebral route: final report. Can J Vet Res 75:152-156

14. Belay ED, Maddox RA, Williams ES, Miller MW, Gambetti P, Schonberger LB (2004) Chronic wasting disease and potential transmission to humans. Emerg Infect Dis 10:977-984

15. Kong Q, Huang S, Zou W, Vanegas D, Wang M, Wu D, Yuan J, Zheng M, Bai $H$, Deng H, Chen K, Jenny AL, O'Rourke K, Belay ED, Schonberger LB, Petersen RB, Sy MS, Chen SG, Gambetti P (2005) Chronic wasting disease of elk: transmissibility to humans examined by transgenic mouse models. J Neurosci 25:7944-7949

16. DEFRA (2016) Cervid spongiform encephalopathy in Norway. https:// www.gov.uk/government/collections/animal-diseases-internationalmonitoring. Accessed 27 Mar 2018

17. Benestad SL, Mitchell G, Simmons M, Ytrehus B, Vikoren T (2016) First case of chronic wasting disease in Europe in a Norwegian free-ranging reindeer. Vet Res 47:88

18. EFSA (2010) Scientific opinion on the results of the EU survey for chronic wasting disease (CWD) in cervids. EFSA J 8:1861

19. Goldmann W (2008) PrP genetics in ruminant transmissible spongiform encephalopathies. Vet Res 39:19

20. Vaccari G, Panagiotidis CH, Acin C, Peletto S, Barillet F, Acutis P, Bossers A, Langeveld J, van Keulen L, Sklaviadis T, Badiola JJ, Andreeoletti O, Groschup MH, Agrimi U, Foster J, Goldmann W (2009) State-of-the-art review of goat TSE in the European Union, with special emphasis on PRNP genetics and epidemiology. Vet Res 40:48

21. O'Rourke KI, Besser TE, Miller MW, Cline TF, Spraker TR, Jenny AL, Wild MA, Zebarth GL, Williams ES (1999) PrP genotypes of captive and free-ranging Rocky Mountain elk (Cervus elaphus nelsoni) with chronic wasting disease. J Gen Virol 80:2765-2769

22. Hamir AN, Gidlewski T, Spraker TR, Miller JM, Creekmore L, Crocheck M, Cline T, O'Rourke KI (2006) Preliminary observations of genetic susceptibility of elk (Cervus elaphus nelsoni) to chronic wasting disease by experimental oral inoculation. J Vet Diagn Invest 18:110-114

23. Green KM, Browning SR, Seward TS, Jewell JE, Ross DL, Green MA, Williams ES, Hoover EA, Telling GC (2008) The elk PRNP codon 132 polymorphism controls cervid and scrapie prion propagation. J Gen Virol 89:598-608

24. Perucchini M, Griffin K, Miller MW, Goldmann W (2008) PrP genotypes of free-ranging wapiti (Cervus elaphus nelsoni) with chronic wasting disease. J Gen Virol 89:1324-1328

25. Jewell JE, Conner MM, Wolfe LL, Miller MW, Williams ES (2005) Low frequency of PrP genotype 225SF among free-ranging mule deer (Odocoileus hemionus) with chronic wasting disease. J Gen Virol 86:2127-2134

26. Fox KA, Jewell JE, Williams ES, Miller MW (2006) Patterns of PrPCWD accumulation during the course of chronic wasting disease infection in orally inoculated mule deer (Odocoileus hemionus). J Gen Virol 87:3451-3461

27. Johnson C, Johnson J, Clayton M, McKenzie D, Aiken J (2003) Prion protein gene heterogeneity in free-ranging white-tailed deer within the chronic wasting disease affected region of Wisconsin. J Wildl Dis 39:576-581

28. O'Rourke KI, Spraker TR, Hamburg LK, Besser TE, Brayton KA, Knowles DP (2004) Polymorphisms in the prion precursor functional gene but not the pseudogene are associated with susceptibility to chronic wasting disease in white-tailed deer. J Gen Virol 85:1339-1346
29. Johnson C, Johnson J, Vanderloo JP, Keane D, Aiken JM, McKenzie D (2006) Prion protein polymorphisms in white-tailed deer influence susceptibility to chronic wasting disease. J Gen Virol 87:2109-2114

30. Marco J, Herrero J, Escudero MA, Fernández-Arberas O, Ferreres J, García-Serrano A, Giménez-Anaya A, Labarta JL (2011) Veinte años de seguimiento poblacional de ungulados silvestres de Aragón. Pirineos. Revista de Ecología de Montaña 166:135-153 (in Spanish)

31. Herrero J, Escudero E, Fernández de Luco D, García-González R (2011) El sarrio pirenaico. Rupicapra p. pyrenaica: Biología, patología y gestión. Publicaciones del Consejo de Protección de la Naturaleza de Aragón. ISBN: 84-89862-47-8 (in Spanish)

32. Bossers A, Schreuder BE, Muileman IH, Belt PB, Smits MA (1996) PrP genotype contributes to determining survival times of sheep with natural scrapie. J Gen Virol 77:2669-2673

33. Goldmann W, Ryan K, Stewart P, Parnham D, Xicohtencatl R, Fernandez N, Saunders G, Windl O, González L, Bossers A, Foster J (2011) Caprine prion gene polymorphisms are associated with decreased incidence of classical scrapie in goat herds in the United Kingdom. Vet Res 42:110

34. Spraker TR, O'Rourke KI, Balachandran A, Zink RR, Cummings BA, Miller MW, Powers BE (2002) Validation of monoclonal antibody F99/97.6.1 for immunohistochemical staining of brain and tonsil in mule deer (Odocoileus hemionus) with chronic wasting disease. J Vet Diagn Investig 14:3-7

35. Peletto S, Perucchini M, Acín C, Dalgleish MP, Reid HW, Rasero R, Sacchi P, Stewart P, Caramelli M, Ferroglio E, Bozzetta E, Meloni D, Orusa R, Robetto S, Gennero S, Goldmann W, Acutis PL (2009) Genetic variability of the prion protein gene (PRNP) in wild ruminants from Italy and Scotland. J Vet Sci 10:115-120

36. Dagleish MP, Martin S, Steele P, Finlayson J, Siso S, Hamilton S, Chianini F, Reid HW, Gonzalez L, Jeffrey M (2008) Experimental transmission of bovine spongiform encephalopathy to European red deer (Cervus elaphus elaphus). BMC Vet Res 4:17

37. Dagleish MP, Martin S, Steele P, Finlayson J, Eaton SL, Siso S, Stewart P, Fernandez-Borges N, Hamilton S, Pang Y, Chianini F, Reid HW, Goldmann W, Gonzalez L, Castilla J, Jeffrey M (2015) Susceptibility of European red deer (Cervus elaphus elaphus) to alimentary challenge with bovine spongiform encephalopathy. PLoS One 10:e0116094

38. Wik L, Mikko S, Klingeborn M, Steen M, Simonsson M, Linne T (2012) Polymorphisms and variants in the prion protein sequence of European moose (Alces alces), reindeer (Rangifer tarandus), roe deer (Capreolus capreolus) and fallow deer (Dama dama) in Scandinavia. Prion 6:256-260

39. Acín C, Martín-Burriel I, Monleón E, Lyahyai J, Pitarch JL, Serrano C, Monzon M, Zaragoza P, Badiola JJ (2013) Prion protein gene variability in Spanish goats. Inference through susceptibility to classical scrapie strains and pathogenic distribution of peripheral PrPsc. PLoS One 8:e61118

40. Moore RA, Vorberg I, Priola SA (2005) Species barriers in prion diseasesbrief review. Arch Virol Suppl 19:187-202

41. Hamir AN, Miller JM, Cutlip RC, Kunkle RA, Jenny AL, Stack MJ, Chaplin MJ, Richt JA (2004) Transmission of sheep scrapie to elk (Cervus elaphus nelsoni) by intracerebral inoculation: final outcome of the experiment. J Vet Diagn Investig 16:316-321

42. Greenlee JJ, Smith JD, Kunkle RA (2011) White-tailed deer are susceptible to the agent of sheep scrapie by intracerebral inoculation. Vet Res 42:107

Ready to submit your research? Choose BMC and benefit from:

- fast, convenient online submission

- thorough peer review by experienced researchers in your field

- rapid publication on acceptance

- support for research data, including large and complex data types

- gold Open Access which fosters wider collaboration and increased citations

- maximum visibility for your research: over 100M website views per year

At BMC, research is always in progress.

Learn more biomedcentral.com/submissions 